\title{
Courtney Page-Tan* \\ The Role of Social Media in Disaster Recovery Following Hurricane Harvey
}

https://doi.org/10.1515/jhsem-2018-0054

Received September 4, 2018; accepted September 11, 2020

\begin{abstract}
Hurricane Harvey was social media's first real stress test as a disaster response and recovery mechanism. A confluence of conditions makes it an ideal case study of social media's role in disaster recovery: the lack of a governmentissued evacuation order, a call from government leadership for willing and able volunteers with a boat or high-water vehicle to perform life-saving rescues, and wide-spread adoption of social media platforms in the Houston area. While research on online social networks and disasters continues to grow, social scientists know little about how these online networks transform during a crisis and, further, how they drive disaster outcomes. With two original datasets, this study investigates how Houston's online social network transformed during Hurricane Harvey (2017), and the relationship between social media activity and post-Harvey recovery. The findings of a social network analysis $(\mathrm{N}=2,387,610)$ and subsequent statistical analyses reveal the Houston-area online social network grew denser, clustered, and more efficient during the disaster. A spatial analysis and three separate regression models of activity before, during, and after Hurricane Harvey reveal that among 333 Nextdoor Neighborhoods, hyperlocal social media activity was a statistically significant predictor of the rate of rebuilding in these geographically based online communities. These findings suggest that policy and decision-makers should invest into online and offline hyperlocal social networks well before a disaster strikes, and leverage resources and legislation to maintain and strengthen the telecommunications and energy infrastructure that supports
\end{abstract}

Courtney Page-Tan is an Assistant Professor of Human Resilience in the Department of Security and Emergency Services at Embry-Riddle Aeronautical University - Worldwide.

This research was partially funded by a Quick Response Grant from the Natural Hazards Center at the University of Colorado - Boulder and a Graduate Student Research and Experiential Learning Grant from Northeastern University.

*Corresponding author: Courtney Page-Tan, Ph.D., Department of Security and Emergency Services, Embry-Riddle Aeronautical University Worldwide and Online, Daytona Beach, FL, USA, E-mail: courtneypagetan@gmail.com 
access to social media and telecommunications infrastructure during a time of crisis.

Keywords: GIS, Hurricane Harvey, resilience, social media, social network analysis, spatial analysis

\section{Introduction}

The headlines that emerged from Hurricane Harvey in 2017 hailed social media as a "savior" (Newcomb 2017). Forty-eight hours into the Category 4 hurricane that descended upon the Houston area, first responders were overwhelmed with calls for thousands of water rescues (Hayden 2017). It was at this point the chief executive of Harris County, Judge Ed Emmett, called on citizens with boats and highwater vehicles to perform water rescues (CBF 2017). This call resulted in a bottomup citizen-led effort resulting in an estimated 7600 crowdsourced water rescues from social media posts and replies over the course of three days (Sullivan and Holley 2017). Three conditions make Hurricane Harvey remarkably different from recent, similar large-scale disasters on the mid-Texas coast such as Hurricanes Ike (2008) or Rita (2005): the absence of a government-ordered mandatory evacuation, the prevalence and wide-spread use of social media and mobile technology, and a call from Harris County leaders to the willing and able to make water rescues. We are still learning about the real-world implications of online social ties following a disaster; that tweets about social resources, instead of infrastructure restoration, were better at predicting the likelihood that individuals would rebuild instead of relocate after Hurricane Sandy (Jamali et al. 2019); and that a Facebook user's second-degree network increased the likelihood of evacuation (Metaxa-Kakavouli, Maas, and Aldrich 2018). This study explores social media as a mechanism of disaster recovery.

This research explores the relationship between hyperlocal social media interactions and real-world post-disaster outcomes. In this study, the results of social network, spatial, and statistical analyses reveal that the exogenous shock of Hurricane Harvey temporarily altered the core structure of the online social network in the Houston area. Online interactions surged, and connections grew closer and denser. We know from media reports that platforms such as Facebook, Nextdoor, and Twitter facilitated water rescues, but our understanding of social media's role in disaster recovery following Hurricane Harvey is still limited. The findings of this study reveal that communities active on Nextdoor's platform were more likely to recover at a rate faster than communities that were less active on Nextdoor's platform. This study underscores the importance of investing in and 
advocating for online and offline hyperlocal community building before, during and after disasters. Local policymakers and disaster mitigation managers should consider encouraging communities to adopt the use of hyperlocal social media platforms, like Nextdoor, that facilitate social ties and connections at the most local of levels well before a disaster strikes. In addition to leveraging resources to support community building, policymakers at all levels should consider legislation that maintains and strengthens the reliability of telecommunications and energy infrastructure.

\section{Background}

\subsection{Social Media During a Crisis}

As Facebook, Twitter, Nextdoor, Weibo, and Instagram, among others, have become more popular, scholars have identified social media's utility as a key variable of academic inquiry. During a crisis, social media apps offer a means for individuals and government agencies to broadcast and receive critical information at every stage of a disaster, from preparedness to rescue and recovery (Lachlan et al. 2016; Lai, Chib, and Ling 2018; Tang et al. 2015). Platforms offer users a place to seek out social and emotional support, signal cues for assistance and aid (Bai and Yu 2016; Comfort et al. 1999; Pang and Ng 2016) and serve as a virtual meeting place for communities, from local to transnational, during a crisis (Brengarth and Mujkic 2016). Previous research has focused on a broad array of topics including identifying dynamic uses of and classifications for social media during crisis phases (Houston et al. 2015); uses for situational awareness, survival, crowdsourcing, solidarity, fundraising, and emotional support (Yadav and Rahman 2016); classifications for a growing number of content producers including individuals, emergency agencies, organizations (Houston et al. 2015; Kim and Hastak 2018), and communities, government and news media (Houston et al. 2015).

\subsection{Communication and Situational Awareness}

The majority of empirical studies of social media use during a crisis can be classified into two broad categories: (1) communication and situational awareness and (2) loss and damage estimation. Communication and situational awareness broadly refer to social media as a tool leveraged by its users, both individuals and organizations alike, to communicate crisis-related information, from updates on the storm trajectory, calls and offers for assistance, to collective action 
campaigns (Vieweg et al. 2008). One study of 986,579 tweets during Hurricane Sandy, found that 95 percent of posts could be classified under categories of disaster event updates, response, preparation and situation reports (Wang and Zhuang 2017). Similarly, in a study of the California San Marcos and Rancho Bernardo wildfires in May of 2014, individuals used social media to share information on wildfire damage, response, evacuation, and gratitude to firefighters (Wang, Ye, and Tsou 2016).

Social networks, defined as "interactions between people and organizations, including who knows, works with, or communicates with whom, that can be mapped" (Magsino 2009), expedite information to their members and those associated with them. For example, in 2008 residents of the Tennessee Valley learned primarily via Twitter when 5.4 million cubic tons of coal fly ash spilled into the Tennessee River, and its tributaries as local news networks failed to pick up the story (Sutton 2010; Sutton et al. 2013). Similarly, in 2014, when 7500 gallons of chemicals leaked into the primary water supply in Charleston, West Virginia, 41 Twitter accounts were responsible for the rapid dissemination of information to its residents (Getchell and Sellnow 2016). In the case of the Pakistani Floods in 2010 (Murthy and Longwell 2013), Cyclone Yasi (Taylor et al. 2012) and a 2012 Indonesian Earthquake (Chatfield, Scholl, and Brajawidagda 2013), users relayed information to their network by linking to both formal and informal sources of information, the latter study finding that within 15 min of an early warning tweet from the Indonesian government, the news had reached over four million Twitter users.

\subsection{Loss and Damage Estimation}

Data available to disaster scholars has grown as social media use has trended upwards. Mapping now extends far beyond just vulnerable or damaged physical infrastructure (Herrera-Yagüe et al. 2015; Stefanidis, Crooks, and Radzikowski 2013) in a time of crisis as more geo-referenced data from social media activity is made available to researchers. Researchers have confirmed across a number of events, such as wildfire disruptions (Wang, Ye, and Tsou 2016), the 2014 Napa Valley Earthquake (Wang and Taylor 2018), Hurricane Sandy (Guan and Chen 2014; Kryvasheyeu et al. 2016; Wu and Cui 2018) and Typhoon Haiyan (Deng et al. 2016) that social media activity - often on Twitter - can be spatially coupled with the extent and level of damage left in the wake of a disaster. Similarly, a study of the 2014 UK flooding event found that data from a combination of geotagged 
images posted to social media, optical remote sensing and high-resolution mapping of the terrain could accurately model flood inundation (Rosser, Leibovici, and Jackson 2017). However, another study of tweets from Hurricane Sandy offers a word of caution, as they found that damage and volume of tweets can exhibit a U-shaped relationship. In areas where damage was most severe along the New York and New Jersey coastline, geo-located social media activity was sparse, as individuals were likely displaced and had to seek shelter and safety in an alternative location (Xiao, Huang, and Wu 2015).

\section{Current Study}

This study builds on the argument that resilience is often the outcome of social capital during and after a disaster (Aldrich 2012; Chamlee-Wright and Storr 2009; Dynes 2006; Nakagawa and Shaw 2004). With newly available social media data and innovative methods, this study demonstrates how hyperlocal social media activity, or hyperlocal online social ties, is a statistically significant factor in explaining the rate of recovery after Hurricane Harvey.

The term social capital captures the "social networks and the norms of reciprocity and trustworthiness that arise from them” (Putnam 2000, p. 19). It is the engine that fuels coordination and cohesion between family, friends, associates, and stakeholders to achieve a given goal or outcome that would not otherwise be possible in its absence (Coleman 1988; Woolcock and Narayan 2000). Trust, norms of reciprocity (Putnam 2000), group membership (Bourdieu 1986), goodwill fellowship, mutual sympathy and social engagement (Hanifan 1916) are all important components in the generation and maintenance of social capital. These components make up a social structure that facilitates actions within it. The positive externalities of social capital include mutual support, cooperation, trust, and institutional effectiveness; however, these close bonds can also lead to sectarianism, ethnocentrism, or corruption (Putnam 2000).

Disaster scholars have consistently demonstrated that communities with strong levels of social capital are better at bouncing back after a disaster. Following the 1923 Tokyo earthquake, some precincts experienced higher growth rates, while others failed to recall their people to rebuild. It was voter turnout from municipal elections and the number of political demonstrations prior to the earthquake that were the most significant drivers of recovery and repopulation in Tokyo following the 1923 earthquake (Aldrich 2012). In a study of nine wards in Kobe, Japan, wards with newly created neighborhood-level NPOs and CBOs experienced higher levels of rebuilding after the 1995 Kobe earthquake (Aldrich 2011). 
Following Hurricane Katrina, repopulation (Rackin and Weil 2015) and a neighborhood's ability to keep FEMA trailers (viewed as a 'public bad') out (Aldrich 2012) were driven primarily by social capital. Communities with higher rates of associational membership and collective efficacy experienced significantly higher return rates, perhaps because they had more confidence in returning to their neighborhoods because they were socially viable compared to neighborhoods that had less investment in and attachment to their communities (Rackin and Weil 2015). Presidential turnout rates in 2004 were indicative of the ability of communities across New Orleans to prevent unwanted trailer sitings after Katrina, which simultaneously thwarted and slowed recovery rates across the city of New Orleans. Areas with upwards of 80 percent voter turnout received fewer than 100 trailers, whereas communities that struggled to turnout a mere 30 percent of its residents to vote received upwards of 1000 trailers (Aldrich 2012).

This study broadens our current understanding of social capital to include online social ties and executes the analyses in two stages. In the first stage, this study uses a social network analysis and four separate one-way ANOVAs to test $\mathrm{H}_{1}$ : At the peak of Hurricane Harvey, Houston-area social networks grew denser, clustered, and more efficient. More specifically, this first test examines how hyperlocal online social networks transformed before, during, and after Hurricane Harvey in the months of August and September of 2017. In the second stage, this study employs spatial and statistical methods to test $\mathrm{H}_{2}$ : Neighborhoods with higher levels of social media use before, during, and after Hurricane Harvey rebuilt at a faster pace compared to those with less social media use.

\subsection{Hurricane Harvey}

Unlike recent hurricanes on the mid-Texas coast such as Hurricanes Ike (2008) and Rita (2005), then Harris County Chief Executive Judge Ed Emmett ordered individuals to shelter in place and stay off the roads in the hours leading up to Hurricane Harvey's landfall. Based on my post-Harvey interviews with senior-level Harris County officials (Sanchez 2017), the recent memory of complications from an evacuation order in advance of Hurricane Rita in 2005 weighed heavily on key decision-makers leading up to Harvey's arrival. In retrospect, the decision to evacuate the Houston area in the hours leading up to Hurricane Rita is considered by most as an over-reaction based on the catastrophic flooding and subsequent human suffering caused by Hurricane Katrina just two weeks prior to Rita. The evacuation order in 2005 led to the worst gridlock ever witnessed in Houston. Many drivers waited more than $20 \mathrm{~h}$ to escape the city limits. With the rising heat in 
Houston mid-September, fights broke out along the interstate and heatstroke claimed the lives of dozens. All told, more than 100 deaths have been linked to the forced egress (Levin 2017), almost equal to the number of lives claimed directly by Hurricane Rita.

When Hurricane Harvey made landfall in the Houston area on August 25th, 2017 it hovered over the city for days. It dropped 60 inches of rainfall between August 25th and August 31st (Zelinsky and Blake 2018), peaking on August 29th. Initially, it picked up speed east of Barbados on August 16th and intensified to a Category 4 hurricane by the time it reached the mid-Texas coast. Between the storm surge and tide, Harvey produced storm inundation levels between six and ten feet in some coastal communities (Zelinsky and Blake 2018). Factors beyond flood inundation, such as population growth, an aging infrastructure (van Oldenborgh et al. 2017), and controlled dam releases by the City of Houston exacerbated the levels of damage and displacement. The storm resulted in 70 fatalities, an estimated $\$ 125$ billion in economic damage, 300,000 flooded structures (many of which were homes), widespread power outages (Jonkman et al.2018), and a total of 122,331 rescues (FEMA 2017).

In the first two days of Harvey's arrival, it became clear that thousands of households in the greater Houston area would need to be evacuated. At the peak of the storm, Houston's 911 Emergency Dispatch Center was overloaded with calls for water rescues. On August 27th, Judge Ed Emmett called upon Houston residents with access to boats and high-water vehicles to help their fellow neighbors. As the hurricane intensified, social media offered the infrastructure for a bottom-up citizen-led emergency network to emerge overnight. Headlines like "Social Media Becomes a Savior in Hurricane Harvey Relief” and "Hurricane Harvey Victims Turn to Social Media for Assistance: With local 911 systems failing, residents are taking to Facebook and Twitter" were quick to emerge as Hurricane Harvey battered the City of Houston and \#sosHarvey, \#helphouston, and @HarveyRescue trended.

In an interview with Police Officer Angela Douglas (Douglas 2017), the Houston Police Department's Social Media Coordinator during Harvey, she described the blitz of incoming calls for help on social media platforms like "drinking water from a fire hose." Francisco Sanchez, Deputy Emergency Management Coordinator, heralded citizen-led rescue efforts during Harvey but recalled the time and energy his staffers spent dispelling myths and rumors that were quick to circulate on social media platforms, such as insurance scams and rumors claiming an unsafe water supply and restrictions on returning to the city in the days and weeks following Harvey (Sanchez 2017).

By August 30th, the storm had finally lifted. Harvey made its final landfall in southwestern Louisiana, 135 miles east of Houston, before being downgraded to a 
tropical depression that dissipated over the Tennessee Valley on September 1st, 2017 (Zelinsky and Blake 2018). In its wake, Harvey left a path of 200 million cubic yards of debris, forced 39,000 people into temporary shelters, and damaged 204,000 homes (NVOAD 2019).

Hurricane Harvey revealed that social media platforms offer a powerful public good during a disaster. Yet, beyond facilitating water rescues, few studies have explored the linkage of social media activity and real-world post-disaster outcomes. Only recently have we learned that tweets about social activities, versus infrastructure restoration, motivated individuals to rebuild instead of relocate following Hurricane Sandy (Jamali et al. 2019); that WeChat was a resource for the Chinese immigrant community to access support, search and rescue assistance, and materials assistance in Houston following Hurricane Harvey (Chu and Yang 2020); and that second-degree networks on Facebook were better at predicting the likelihood that an individual would evacuate during Hurricane Maria (Metaxa-Kakavouli, Maas, and Aldrich 2018). Post-disaster outcomes can include short-and long-term recovery activities, such as providing food and shelter for those unable to safely return home, restoring critical infrastructure and utilities (Baird 2010), clearing debris, and rebuilding. As discussed in the previous section, researchers of social capital have demonstrated that strong offline social ties can expedite these activities.

As we will see, the large shock of dealing with a natural disaster temporarily altered the fundamental structure of the online social network of Houston during Hurricane Harvey. Subsequent analyses reveal a statistically significant relationship between online social ties on Nextdoor's hyperlocal platform before, during, and after the disaster and a reduction in the number of days it took individuals to recover.

\section{Methods and Data}

This study undertakes a two-stage analysis to understand the relationship between online hyperlocal social media activity on Nextdoor's social media platform and real-world disaster outcomes following Hurricane Harvey. In the first stage, data from an exclusive ${ }^{1}$ partnership with Nextdoor is analyzed in Gephi and STATA to determine if there are significant changes in social media use at three critical

1 This exclusive, voluntary, and non-compensatory partnership with Nextdoor began in late 2014, and was formalized first in 2015 at Purdue University, and most recently, in September of 2017 with a Memorandum of Understanding between Nextdoor, Daniel Aldrich, and myself regarding the data collected for this study. In the formalized agreement, all parties agreed to mutual terms of data usage and storage based on a query conducted by Nextdoor for the purpose of research to better understand the role of social connections and social media during disaster. The query was conducted in October of 2017 at the Nextdoor headquarters in San Francisco, CA, where I worked with a data scientist to 
periods: before, during, and after Hurricane Harvey. In the second stage, measures of recovery plotted in ArcGIS are spatially joined and regressed on social media data aggregated by Nextdoor Neighborhood and by disaster phase: before, during, and after Hurricane Harvey.

\subsection{About Nextdoor}

Nextdoor is a hyperlocal social media platform. Present in more than 265,000 communities worldwide (Nextdoor 2020), it has dense market saturation in the City of Houston from pre-Harvey to present day. It offers a platform for neighbors to organize events such as block parties, or associations like Neighborhood Watch Groups. The mission statement on their website states that they "believe that the neighborhood is one of the most important and useful communities in a person's life" ... and have designed their platform to "build stronger and safer neighborhoods around the world."

There are three distinct characteristics of Nextdoor's platform that set it apart from other social media firms. First, the platform is hyperlocal. Nextdoor is a platform designed with local neighborhoods in mind. When someone registers with Nextdoor, they are grouped with members of their local neighborhood, called a Nextdoor Neighborhood ("Neighborhood"). The geographic boundaries of Neighborhoods are crowdsourced by its members (Fagin 2017). Imagine drawing a circle around what you consider to be your neighborhood. This is one of the tasks the app prompts its users to complete when they first register. Nextdoor feeds data from multiple entries from local users to estimate the best boundary for each Neighborhood. This process is designed so that its members online are the people the user sees everyday walking their dog, mowing their lawn, and coming home from work.

Second, the platform is exclusive. While free and open to all, the geographic neighborhoods themselves are exclusive to those who live within them. For example, someone living in New York City could not become a member of a Neighborhood in Columbus, Ohio, without actually providing a physical address that can be later verified to be true by Nextdoor. This ensures that the members in each Neighborhood, again, are actually nextdoor neighbors.

Finally, Nextdoor requires that users use their real identity when you register on the platform. This distinguishes Nextdoor from competitors like Facebook and

define the query to ensure we were capturing the data to support the research design. Data were aggregated at the Nextdoor neighborhood level to protect the privacy of its users.

2 Nextdoor. (2020). About us. Retrieved from https://nextdoor.com/about_us/. 
Twitter. The people in your neighborhood are verified by Nextdoor to ensure that they are in fact who they say they are online. Nextdoor verifies its users in two ways: first, new users can receive a mailed postcard invitation to join when a neighbor has nominated them to become a member by providing their information to Nextdoor. Individuals receive a verification code on the postcard to verify their identity when they register online. Alternatively, Nextdoor has a contact form indivduals can fill out and send in with a copy of a valid ID, deed or rental agreement, utlity bill, or letter from a bank or authorized insurer (Nextdoor 2020).

The original dataset acquired from Nextdoor consists of 3,061,805 interactions from the beginning of July through the end of September 2017 that took place across all Nextdoor Neighborhoods in Texas, ranging from 1 to 7045 members, with an average of 643 members. Interactions between Nextdoor Neighborhoods were reported in dyads, time-stamped, with latitude and longitude of the centroid of the Nextdoor Neighborhood. Interactions include posts, replies, and “Thanks," a preprogrammed button members can click to respond to a post.

H1: At the peak of Hurricane Harvey, Houston-area social networks grew denser, clustered, and more efficient.

In stage one, the primary and singular unit of analysis is the Nextdoor online social network in Houston, which consists of Nextdoor Neighborhoods and their interNeighborhood interactions. In this study, a social network analysis (SNA) is conducted in Gephi and STATA on 2,387,610 online interactions that took place on the Nextdoor platform before, during, and after the storm in the months of August and September of 2017 to obtain four key measures of network structural properties: average degree, network diameter, path length, and clustering. Differences in these key measures before, during, and after Harvey are identified by carrying out four independent one-way ANOVAs.

An SNA "is the identification of the relationships and attributes of members, key actors, and groups that social networks comprise” (Magsino 2009). Applying

Table 1: Stage one analysis descriptive statistics of daily network analyses from August 1st to September 30th, 2017.

\begin{tabular}{llrrrr}
\hline Variable & n & Mean & Std. Dev. & Min & Max \\
\hline Average degree & 61 & 4.06 & 1.44 & 3.05 & 9.37 \\
Network diameter & 61 & 40.43 & 11.23 & 20.00 & 70.00 \\
Path length & 61 & 12.74 & 3.06 & 6.28 & 20.42 \\
Clustering coefficient & 61 & 27.59 & 4.28 & 22.70 & 40.50 \\
\hline
\end{tabular}



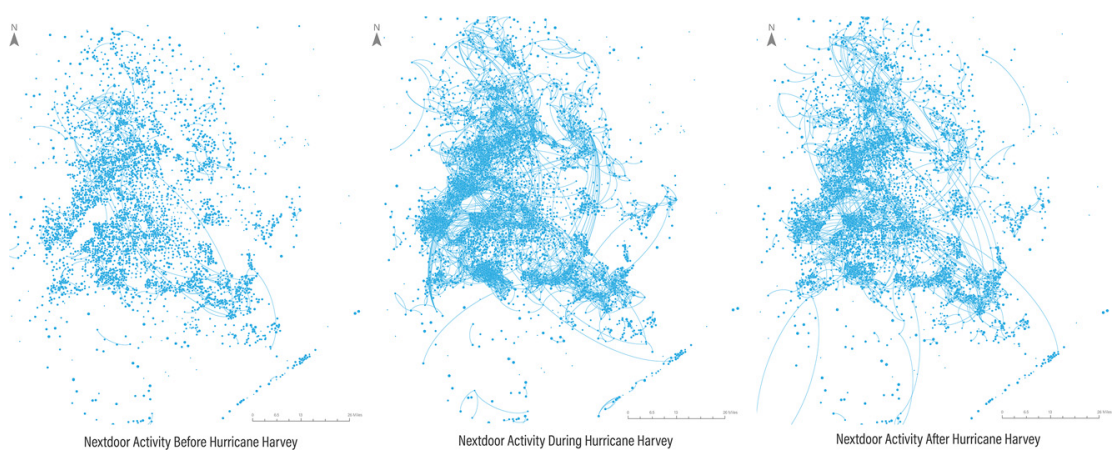

Figure 1: Maps of interactions between Nextdoor Neighborhoods before, during, and after Hurricane Harvey. Note: Visuals produced in Gephi with the ForceAtlas 2 layout and Adoble Illustrator.

an SNA to a large-scale disaster like Hurricane Harvey is not novel. Researchers have explored the dynamics of social networks at the individual, community and governmental level for crises and disasters such as the September 11th Terrorist Attacks (Kapucu 2005, 2006; Kapucu and Van Wart 2006; Schweinberger, Petrescu-Prahova, and Vu 2014), Venezuelan political protests in 2010 (Morales et al. 2014), the Shifang Protests in the Sichuan Province of China (Shi et al. 2017), Hurricane Andrew (Beggs, Haines, and Hurlbert 1996; Hurlbert, Haines, and Beggs 2000; Hurlbert, Beggs, and Haines 2001), Hurricanes Katrina and Rita (Kapucu, Arslan, and Collins 2010), Hurricanes Ivan, Jeanne, Charley and Frances (Kapucu, Bryer, and Arsian 2010), the 2014 West Virginia Water Crisis (Getchell and Sellnow 2016), the 2016 flood in Louisiana (Kim and Hastak 2018), the Great East Japan Earthquake and Tsunami (Bisri 2016) and reconstruction following the 2004 Indian Ocean Tsunami (Lassa 2015). Most recently, researchers (Kim and Hastak 2018) found that individuals made up the core of online social networks on Facebook and Twitter during the 2016 Louisiana Flood using the two platforms to share information and communicate with City officials in Baton Rouge, placing emergency agencies and organizations on the periphery of the mapped social network.

Key measures of average degree, network diameter, path length, and clustering across nodes in the Houston area are derived from the social network analysis. In this SNA, nodes represent Nextdoor Neighborhoods. Average degree, also known as local centrality, is a basic measure of incoming and outgoing interactions of a node (Scott 2012). As degree increases in a network, more communication is taking place in the network. Network diameter, used as a measure of betweenness centrality, is the longest path between two connected nodes in the overall network. This measure often indicates how quickly information is transmitted across an entire network. Similarly, path length is the mean length 
Table 2: Stage two analysis descriptive statistics of the rate of recovery, nextdoor activity, and demographic and environmental factors.

\begin{tabular}{|c|c|c|c|c|c|c|}
\hline $\begin{array}{l}\text { Visual of a } \\
\text { segment of data }\end{array}$ & Variable & $\mathbf{n}$ & Mean & Std. Dev & Min & Max \\
\hline \multirow{3}{*}{ 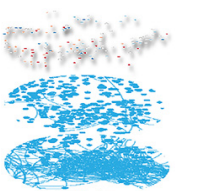 } & Rate of rebuilding & 324 & 126 & 51 & 13 & 245 \\
\hline & $\begin{array}{l}\text { Nextdoor use before Hurri- } \\
\text { cane Harvey }\end{array}$ & 324 & 8 & 22 & 0 & 239 \\
\hline & $\begin{array}{l}\text { Nextdoor use during Hurri- } \\
\text { cane Harvey }\end{array}$ & 333 & 46 & 105 & 0 & 851 \\
\hline & $\begin{array}{l}\text { Nextdoor after Hurricane } \\
\text { Harvey }\end{array}$ & 331 & 13 & 37 & 0 & 429 \\
\hline \multirow[t]{7}{*}{$\operatorname{lop}_{0}$} & $\begin{array}{l}\text { Nextdoor membership } \\
\text { count }\end{array}$ & 324 & 1481 & 1096 & 29 & 5327 \\
\hline & $\begin{array}{l}\text { Percentage of people bach- } \\
\text { elor's, master's, or doctoral } \\
\text { degree }\end{array}$ & 324 & 33 & 22 & 1 & 82 \\
\hline & Median age & 324 & 38 & 7 & 24 & 67 \\
\hline & Median income & 324 & $\$ 84,496$ & $\$ 50,393$ & $\$ 24,865$ & $\$ 302,897$ \\
\hline & $\begin{array}{l}\text { Percentage of households } \\
\text { that use English at home }\end{array}$ & 324 & 56 & 22 & 9 & 93 \\
\hline & Median rainfall, inches & 324 & 34 & 3 & 29 & 45 \\
\hline & Sub-watersheds & 15 & & & 0 & 1 \\
\hline
\end{tabular}

Note: Visual of data segments generated in ArcGIS and Adobe Illustrator.

between all nodes in the network. Transmission of information in a network depends on the path length between pairs. In some cases, information may be transmitted across a network to a pair of nodes that may not even have direct contact or knowledge of one another (Scott 2012). Finally, the clustering coefficient represents the strength of connectivity and closeness between nodes (Pinheiro 2011). For example, if all nodes in a network were connected to one another, the coefficient would be 1 , but if none of the nodes were connected to one another, the coefficient would be 0 .

These key measures are computed using Gephi for each day from August 1st to September 30th, 2017 (see Table 1), a total of 61 days. Days are coded into three categories: before, during, and after Hurricane Harvey. One-way ANOVAs identify significant differences in average degree, network diameter, path length, and clustering across these three time periods. Figure 1 is a visual representation of Nextdoor Neighborhood interactions that took place on August 18th, August 28th, and September 5th, 2017. 


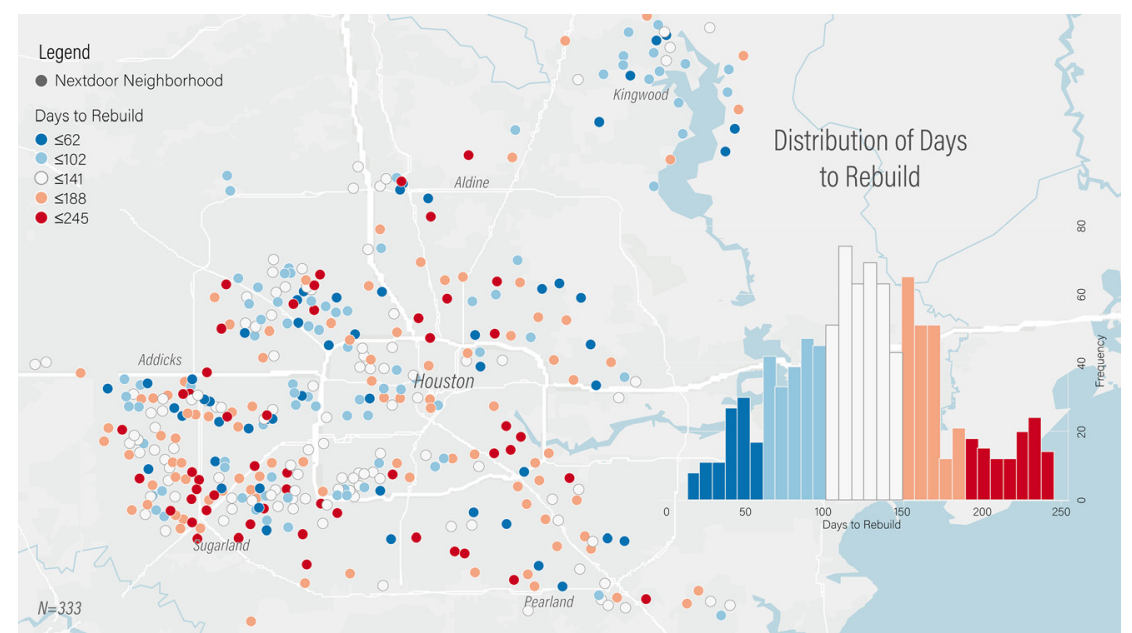

Figure 2: Rate of rebuilding by Nextdoor Neighborhoods. Note: Visual produced in ArcGIS and Adobe Illustrator.

H2: Neighborhoods with higher levels of social media use before, during, and after Hurricane Harvey rebuilt at a faster pace, compared to those with less social media use.

In stage two of the analysis, 333 Nextdoor Neighborhoods in the Houston area are the central unit of analysis and are spatially joined in ArcGIS with the dependent variable, rate of recovery, and Census and environmental data to account for confounding variables (see Table 2). The rate of recovery is operationalized by the number of days it took Houston residents to obtain an elevation certificate from a land surveyor, required by the City of Houston to rebuild in a floodplain. Following a Public Information Request filed with the City of Houston, the Houston Floodplain Management Office provided data on approved applications with the latitude and longitude point data for each household and the date the household was approved to rebuild. A total of 5935 approved applications are included in this dataset, with dates ranging from September 5th, 2017 to May 9th, 2018. The rate of rebuilding is calculated as the delta between the date the first elevation certificate was granted and the date of approval for all other applications, ranging from 0 to 245 days, with a mean of 112 days. For example, an application approved on September 28th, 2017 took 23 days, versus the 175 days it took an applicant to be granted an elevation certificate on February 27th, 2018.

To measure the rate of recovery by Nextdoor Neighborhood, 333 Neighborhood polygons are overlaid on 5935 elevation certificates points in ArcGIS. Houston Nextdoor Neighborhoods range in size from 0.02 square miles to 20.7 square miles, 
with a median size of 0.79 square miles. Executives at Nextdoor shared these polygons for this analysis, but to protect the intellectual property of Nextdoor, polygons are visualized here by their centroid point.

Across 333 Neighborhoods, there is an average of 18 elevation certificates per neighborhood, a minimum of 1 , maximum of 639 , and a standard deviation of 45.37. The mean number of days to rebuild in each Neighborhood is calculated by overlaying the two layers of points and polygons and using the Summarize Within tool to average the number of days to rebuild from all the points in each of the polygons. At the Neighborhood level, it took Nextdoor Neighborhoods an average of 124 days to rebuild, ranging from as few as 13 days to as many as 245 through May 9th, 2018 (see Figure 2).

The key independent variable is the average volume of social media activity of each Nextdoor Neighborhood from three different time periods: before, during, and after Hurricane Harvey. Before Hurricane Harvey, from August 1st to August 23rd, 2017, 324 Nextdoor Neighborhoods averaged eight online interactions per day. During Hurricane Harvey, from August 24th to September 2nd, 333 Neighborhoods averaged 45 online interactions per day. After Hurricane Harvey, from September 3rd to September 30th, 331 Neighborhoods averaged 13 online interactions per day.

\subsection{Alternative Explanations}

Disaster scholars have also identified important human, social, and environmental factors to be strong predictors of disaster outcomes (Dacy and Kunreuther 1969; Edgington 2010; Elliott, Haney, and Sams-Abiodun 2010; Haas, Kates, and Bowden 1977; Horwich 2000; Maxwell 2018; Rackin and Weil 2015; Rodriguez et al. 2006; Tatsuki and Hayashi 2002). In addition to controlling for membership size of each Nextdoor Neighborhood, Neighborhood averages of education, income, language, age, Hurricane Harvey rainfall, and watersheds are included to control for alternative explanations.

Measures of education (percentage of people with a bachelor's, master's, or doctoral degree), median household income, language (percentage of households that use English at home), and median age are based on data from 244 Census Block-Groups. Subwatersheds and mean values from rainfall gauges and Census Block Groups are derived from overlaying each layer with Neighborhood polygons and matching and calculating the statistical attribute.

Watersheds provide an ideal control to account not only for storm inundation but also the controlled dam releases and resultant flooding that took place following the storm. A watershed is sometimes referred to as a drainage basin or 
Table 3: One-way ANOVAs of average degree, network diameter, path length, and clustering before, during, and after Hurricane Harvey.

\begin{tabular}{|c|c|c|c|c|c|}
\hline \multirow[t]{2}{*}{ Variable } & \multirow{2}{*}{$\begin{array}{l}\text { Mean pre- } \\
\text { Harvey }\end{array}$} & \multirow{2}{*}{$\begin{array}{r}\text { Mean during } \\
\text { Harvey }\end{array}$} & \multirow{2}{*}{$\begin{array}{r}\text { Mean after } \\
\text { Harvey }\end{array}$} & \multicolumn{2}{|r|}{ ANOVA } \\
\hline & & & & $\begin{array}{r}\text { Levene } \\
\text { statistic: }\end{array}$ & $\boldsymbol{F}$ \\
\hline Average degree & 3.23 & 6.73 & 3.78 & $41.33^{\star \star \star}$ & $73.16^{\star \star \star}$ \\
\hline Network diameter & 42 & 24.5 & 45.14 & $3.66^{\star \star}$ & $21.16^{\star \star \star}$ \\
\hline Path length & 13 & 8 & 14 & $2.97^{\star}$ & $27.94^{\star \star \star}$ \\
\hline $\begin{array}{l}\text { Clustering } \\
\text { coefficient }\end{array}$ & 25 & 36 & 27 & $13.25^{\star \star \star}$ & $109.22^{\star \star \star}$ \\
\hline
\end{tabular}

${ }^{\star \star \star} p<0.01,{ }^{\star \star} p<0.05,{ }^{\star} p<0.1$.

catchment and is a designated geography that includes streams, rivers, lakes, reservoirs, and underlying groundwater (NOAA 2018). In the case of Hurricane Harvey, the heavy rainfall and controlled dam releases on the Addicks and Barker Reservoirs created conditions in which watersheds were unable to accommodate the large volumes of water that would have normally flowed into the Buffalo Bayou, resulting in extreme flooding in some areas, delaying recovery in several of the neighborhoods located along the Buffalo Bayou. To control for this, twenty-five subwatersheds are included in the analysis. A large percentage of Neighborhoods are located within the Keegans Bayou-Brays Bayou watershed (23\%), followed by the Spring Branch-Buffalo Bayou (14\%), Country Club Bayou-Brays Bayou (10\%), and Cole Creek-Whiteoak Bayou (8\%) watersheds, among others.

\section{Findings}

In the first stage of the analysis, a one-way ANOVA is performed for each of the four key social network analysis measures - average degree, network diameter, path length, and clustering - to determine if the greater Nextdoor online network transformed during Hurricane Harvey compared to rates before and after the storm. Measures of average degree, network diameter, path length, and clustering are taken from 61 consecutive days, from August 1st through September 30th, 2017, Hurricane Harvey occurring between August 24th and September 2nd. Days are classified into three key groups: Before Hurricane Harvey $(n=23)$, During Hurricane Harvey $(\mathrm{n}=10)$, and After Hurricane Harvey $(\mathrm{n}=28)$.

Results of the four one-way ANOVAs reveal significant statistical differences across each of the four key social network analyses (see Table 3): average degree $F(2,58)=73.16, p=0.000$, network diameter $F(2,58)=21.16, p=0.000$, path length 
$F(2,58)=27.94, p=0.000$, and clustering $F(2,58)=109.22, p=0.000$. These findings suggest that we can reject the null hypothesis that there were no observable or significant differences in network structure and metrics at the peak of Hurricane Harvey.

Tukey posthoc tests for all four one-way ANOVAs reveal statistically significant differences. Average degree was statistically significantly higher During Harvey compared to Before Harvey $(3.5 \pm 0.3, p=0.000)$; marginally higher After Harvey compared to Before Harvey $(0.56 \pm 0.22, p=0.0 .037)$; and lower After Harvey compared to During Harvey $(-2.94 \pm 0.29, p=0.000)$. Path length was statistically significantly lower During Harvey compared to Before Harvey $(-5.16 \pm 0.84, p=0.000)$; higher After Harvey compared to During Harvey (6.04 $\pm 0.82, p=0.000)$; yet, statistically insignificant After Harvey compared to Before Harvey $(0.89 \pm 0.63, p=0.339)$. Network diameter was statistically significantly lower During Harvey compared to Before Harvey $(-17.11 \pm 3.29, p=0.000)$; statistically significantly higher After Harvey compared to During Harvey (20.64 \pm 3.20, $p=0.000)$; yet again, statistically insignificant After Harvey compared to Before Harvey $(3.53 \pm 2.44, \mathrm{p}=0.324)$. Finally, clustering was statistically significantly higher During Harvey compared to Before Harvey (11.10 \pm 0.75 , $p=0.000)$; higher After Harvey compared to Before Harvey $(2.62 \pm 0.56, p=0.000)$;
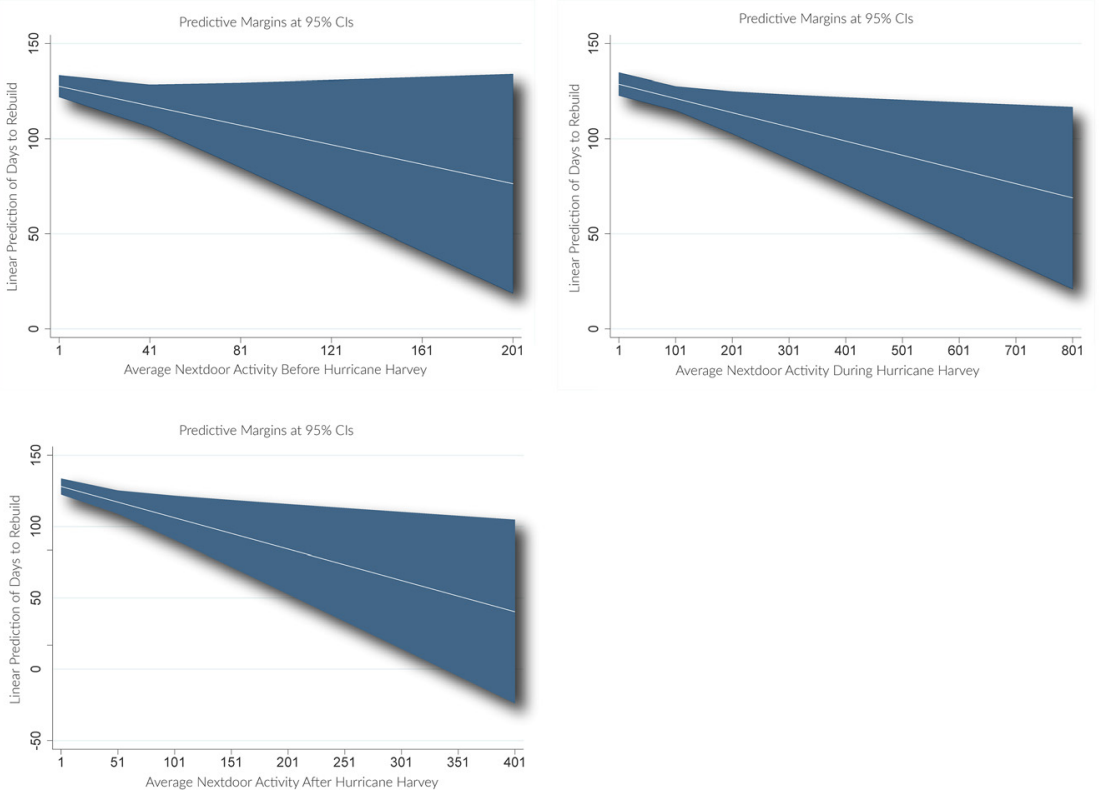

Figure 3: Predicted probability of the rate of rebuilding. 
and statistically significant lower After Harvey compared to During Harvey $(-8.48 \pm 0.56, p=0.000)$.

In the second stage of analysis, the results from three separate regression models with robust standard errors support Hypothesis 2 - that as hyperlocal social media use increased in each of the three stages - before, during, and after we observe a negative and significant relationship with the rate of recovery. In other words, as we observe increases in hyperlocal social media activity, we can expect the number of days to rebuild at the Nextdoor Neighborhood-level to decrease (full regression results displayed in Table 4 in Annex). In Model 1, for every unit increase in the average rate of social media use before Hurricane Harvey, a 0.257 unit decrease in the rate of rebuilding is predicted, holding all other variables constant. In Model 2, for every unit increase in the average rate of social media use during Hurricane Harvey, a 0.0749 unit decrease in the rate of rebuilding is predicted, holding all other variables constant. Finally, in Model 3, for every unit increase in the average rate of social media use after Hurricane Harvey, a 0.219 unit decrease in the rate of rebuilding is predicted, holding all other variables constant. In Models 2 and 3, for every unit increase in Neighborhood membership, we see a 0.00587 and 0.00571 increase, respectively, in the number of days it took Neighborhoods to rebuild. While these coefficients are slight, they indicate that smaller, tight-knit Neighborhoods realize the greatest gains, compared to those with hundreds of members.

In post estimations of predictive margins, the marginal effects at representative values provide a more meaningful and intuitive interpretation, displayed in Figure 3. In Model 1, the predicted probability of the rate of rebuilding goes from 127 days in Nextdoor Neighborhoods with a median of a single post per day before Hurricane Harvey to 76 days in Neighborhoods with a median of 201 posts per day. In Model 2, the predicted probability of the rate of rebuilding goes from 128 days in Neighborhoods with a median of a single post per day during Hurricane Harvey to 69 days in Neighborhoods with a median of 801 posts per day. Finally, in Model 3, the predicted probability of the rate of rebuilding goes from 128 days in Neighborhoods with a median of a single post per day during Hurricane Harvey to 40 days in Neighborhoods with a median of 401 posts per day.

Subwatersheds are - by far - the strongest statistically significant predictors of rebuilding in the Houston area. All three models predict that 12 of the 25 subwatersheds severely delayed the rebuilding process. Averaged across the three models, in order of most to least severe, the Upper Sims Bayou watershed delayed rebuilding by 85 days; Mustang Bayou by 73 days; Seaberg Reservoir-Cedar Bayou by 71 days; Hunting Bayou by 59 days; Keegans Bayou-Brays Bayou and Halls Bayou by 50 days; Luce Bayou-Frontal Lake Houston by 47 days; Country Club Bayou-Brays Bayou by 43 days; Spring Branch-Buffalo Bayou by 35 days; Clear 
Creek-Frontal Galveston Bay by 32 days; Vince Bayou-Buffalo Bayou by 28.30 days (but only in Model 1); and Little Whiteoak Bayou-Whiteoak Bayou by 23 days. Only two subwatersheds across all three models predicted a decline in the number of days it took to rebuild: The Orange Branch-East Fork San Jacinto River less 58 days and the Headwaters Greens Bayou less 17 days.

\section{Analysis}

In the first stage of analysis, findings suggest that at the peak of Hurricane Harvey, the Nextdoor network structure underwent dramatic and statistically significant changes. The network diameter, the maximum distance between the two furthest Nextdoor Neighborhoods in the network, decreased by $41 \%$ and the average path length between Neighborhoods decreased by 39\%. These changes in the network facilitated efficient communication and information sharing between Nextdoor Neighborhoods, as the number of steps it took for information to be passed from one Neighborhood to another was significantly reduced. In some cases, individuals in Nextdoor Neighborhoods were likely receiving key information from users in the network they had never even met.

During the storm, the average degree, or degree centrality, of the greater Nextdoor Neighborhood expanded by $108 \%$. This indicator measures the degree to which Neighborhoods are connected to one another. As this number increased in the Houston area during Hurricane Harvey, Neighborhoods were better positioned to send and receive critical information (Hanneman and Riddle 2005). Finally, the clustering coefficient increased by $44 \%$, indicating that Neighborhoods became increasingly more neighborly with other Neighborhoods, to the extent that new subgroups formed in the Nextdoor network, temporarily altering the core structure of the network during the storm.

Post-hoc tests of network changes before, during, and after Hurricane Harvey reveal significant changes in the network resulting from the exogenous shock of the storm. The tests also revealed significant changes between before and after Harvey, indicating that the large shock of Harvey resulted in some residual changes in the network after the storm. Average degree and clustering coefficient after Harvey are statistically significantly higher compared to rates before Harvey. These two changes in network structure suggest first that a large shock to the network led to lasting effects of increased communication in Neighborhoods. Second, Neighborhoods were surrounded by Neighborhoods that were well connected with one another, which could - in turn - result in lasting effects, which future research must explore. 
Finally, in the first stage of the analysis, posthoc tests of path length and network diameter from before Harvey compared to after Harvey are insignificant, suggesting the reduction in size of the network and paths connecting Neighborhoods was not a lasting effect. This return to normal in network diameter and path length is in and of itself a signal of resilience. During Hurricane Harvey, individuals stranded and in need of rescue were forced to seek help elsewhere after several failed attempts to reach a 911 dispatcher. It was then, at this critical point, that social media did, in fact, become a "savior," offering a platform for individuals to post and respond to calls for help. As the storm lifted and moved east, we see the overall network relax and return to pre-Harvey rates, indicating the immediate response phase of the disaster had passed.

In the second stage of analysis, findings reveal that as the rate of interactions before, during, and after Hurricane Harvey increased, the number of days it took Nextdoor Neighborhoods to recover decreased. This finding is consistent with the literature on the importance of social capital, defined as "a social asset by virtue of actors' connections and access to resources in the network or group of which they are members (Lin 2001) (p19)" during a disaster pre-event, event and post-event. While previous research has explored the linkages between social capital and social media (Boase et al. 2006; Burke, Kraut, and Marlow 2011; Chai and Kim 2010; Chen and Li 2017; Chiu, Hsu, and Wang 2006; Gil de Zúñiga, Jung, and Valenzuela 2012; Hau and Kim 2011; Kittilson and Dalton 2011; Lee and Lee 2010; Quinn 2016; Shah, Kwak, and Holbert 2001), and while some have found that virtual interactions can mirror in-person interactions (Dunbar et al. 2015), up until now, the linkage between these online hyperlocal social ties and real-world outcomes has been largely unexplored. In this case, we observed that social ties and activity on the Nextdoor platform resulted in observable and statistically significant differences in the rate of recovery.

Interviews I conducted with residents in Houston in October of 2017 following Harvey triangulate these statistical findings. In one-on-one interviews, residents from the Energy Corridor of Houston shared that "Nextdoor was a place to share information and recovery vendors after Harvey ..." and that "the membership [after Harvey] went through the roof because people realized they could go on Nextdoor for help." Further, residents recalled that before Hurricane Harvey "the platform [Nextdoor] helped [our] neighbors [get] to know each other a little better. It has helped POA [Property Owner's Association] boards recognize issues at faster pace. [It has] given folks a heightened sense of security," echoed by another individual, that "Nextdoor helped create an intimacy before Harvey."

These findings have broader implications for the building community resilience, defined as a "neighborhood's capacity to weather crises such as disasters and engage in effective and efficient recovery through coordinated efforts and 
cooperative activities (Aldrich 2012) (p7)," as offline connections have in cases such as Hurricane Katrina (Adeola and Picou 2012; Airriess et al. 2008; Aldrich 2012; Chamlee-Wright and Storr 2009; Hawkins and Maurer 2010; Rackin and Weil 2015) and the 1995 Kobe Earthquake (Sawada and Shimizutani 2008; Tatsuki and Hayashi 2002).

\section{Discussion}

Resilience to disasters is not a silo, but a system. Policymakers should draw upon two important implications of this study: (1) invest in hyperlocal communities (online and offline) before a crisis and (2) support the emergent class of tech-based first responders by investing in the energy and telecommunications infrastructure needed to support the bandwidth needed to facilitate critical communication. Without this necessary infrastructure, individuals would lose access to a vast network of individuals, both known and unknown, with access to information and resources beyond another's reach.

Investing in social ties, or social capital, before a disaster mitigates damage and fatalities and accelerates recoveries, with specific benefits such as better access to resources (Hawkins and Maurer 2010), reduced mortality rates (Aldrich and Sawada 2015; Klinenberg 2002), expedited repopulation and rebuilding (Aldrich 2012), and easier collective action before, during and after disasters (ChamleeWright and Rothschild 2007; Nakagawa and Shaw 2004; Rackin and Weil 2015). By investing in these relationships before a crisis, communities are better equipped to withstand not only inclement weather events but also social, civil and political disturbances that can tug at the fabric of a community.

Nextdoor, like all social media firms such as Facebook and Twitter, maintain servers so that its users can access their hyperlocal network on-demand with ease and speed, and they use a fleet of engineers to maintain and improve upon their network. Telecommunication giants such as AT\&T, Sprint, T-Mobile, and Verizon and Texas utility companies like First Choice Power, Direct Energy, TXU Energy, Trieagle Energy, and Frontier Utilities are among the many unsung heroes during Harvey. While outages are expected, these companies provided the energy and telecommunications infrastructure the Houston area required to maintain online networks used to share, broadcast, and receive critical information.

Social media platforms alongside telecommunications and utility companies have demonstrated their worth in a time of crisis. Following Hurricane Maria, AT\&T restored wireless service to some areas in Puerto Rico with LTE-equipped drones (Brodkin 2017). In late 2016, Facebook was reportedly experimenting with 
solar-powered drones and high-bandwidth radio antennas to deliver internet to areas stricken by disaster (Metz 2016).

Policymakers should consider how resources and legislation can be leveraged to support the emergence of this new class of first responders by encouraging innovation, supporting cutting-edge disaster resilience research, promoting policies that grow new (online and offline) social ties, reinforce existing ones across communities and support companies that offer vital public services during a crisis.

\section{Future Research and Limitations}

Future research should explore the role rival social media platforms have on disaster outcomes, like Facebook, Twitter, and WeChat, among others. Nextdoor provides a unique hyperlocal platform. During Hurricane Harvey, its members were connected to nearby neighborhoods experiencing the same crisis, with members who could answer calls for help and provide water rescues within minutes or hours following a post, which also supports the argument that disaster can bring out the best in individuals (Solnit 2009). Results from platforms like Facebook and Twitter with thriving communities without geographic boundaries may produce different outcomes.

Researchers should explore how platforms like Facebook and Twitter transform during a crisis and how they drive resilience outcomes. While these networks without borders may not provide immediate assistance during a crisis like Nextdoor's platform, they may be strong drivers of post-disaster recovery, offering temporary housing outside of storm inundation zones in the days, week and months after a disaster, as was the case following Hurricane Katrina (Elliott, Haney, and Sams-Abiodun 2010) or cash or in-kind donations to those in their networks who lost everything during a disaster.

Further, access to big data ${ }^{3}$ from social media and crowdsourcing applications like TenFour, Ushahidi, Sahana, and Citizens to the Rescue would also offer researchers the opportunity to understand how disaster-oriented mobile platforms interact with disaster outcomes, but also when individuals are unable to access these resources, and if, when, and why there are bottlenecks on the network. Understanding the differences text, audio, picture, and video messages have on network efficacy and

3 Big data is conceptualized "not just as large datasets, some of which have been used for decades in climatology, but as a new socio-technological phenomenon resulting from the emergence and development of an ecosystem made up of the new kinds of data 'crumbs' about human behaviours and beliefs generated and collected by digital devices and services, ever more powerful computing power and analytics tools, and a vibrant community of actors in this field" (Alliance 2015). 
Table 4: Regression models of nextdoor social media use before, during, and after Hurricane Harvey driving community rebuilding in Houston.

\begin{tabular}{|c|c|c|c|}
\hline & Model 1 & Model 2 & Model 3 \\
\hline \multicolumn{4}{|l|}{ Independent Variables } \\
\hline Social media use before Hurricane Harvey & $\begin{array}{r}-0.257^{\star \star} \\
(0.115)\end{array}$ & & \\
\hline Social media use during Hurricane Harvey & & $\begin{array}{r}-0.0749^{\star \star \star} \\
(0.0264)\end{array}$ & \\
\hline Social media after Hurricane Harvey & & & $\begin{array}{r}-0.219^{\star \star \star} \\
(0.0526)\end{array}$ \\
\hline \multicolumn{4}{|l|}{ Control Variables } \\
\hline Nextdoor membership & $\begin{array}{r}0.00365 \\
(0.00295)\end{array}$ & $\begin{array}{r}0.00587^{\star \star} \\
(0.00297)\end{array}$ & $\begin{array}{c}0.00571^{\star \star} \\
(0.00283)\end{array}$ \\
\hline Mean education & $\begin{array}{r}-0.186 \\
(0.259)\end{array}$ & $\begin{array}{l}-0.243 \\
(0.272)\end{array}$ & $\begin{array}{l}-0.270 \\
(0.269)\end{array}$ \\
\hline Mean age & $\begin{array}{l}-0.117 \\
(0.717)\end{array}$ & $\begin{array}{r}-0.0713 \\
(0.702)\end{array}$ & $\begin{array}{r}-0.0856 \\
(0.713)\end{array}$ \\
\hline Mean income & $\begin{array}{r}5.18 \mathrm{e}-05 \\
(9.76 \mathrm{e}-05)\end{array}$ & $\begin{array}{r}8.46 \mathrm{e}-05 \\
(9.79 \mathrm{e}-05)\end{array}$ & $\begin{array}{r}9.13 \mathrm{e}-05 \\
(9.82 \mathrm{e}-05)\end{array}$ \\
\hline Mean language & $\begin{array}{r}-0.174 \\
(0.209)\end{array}$ & $\begin{array}{l}-0.180 \\
(0.215)\end{array}$ & $\begin{array}{r}-0.166 \\
(0.218)\end{array}$ \\
\hline Hurricane Harvey rainfall & $\begin{array}{r}1.235 \\
(1.266)\end{array}$ & $\begin{array}{r}1.331 \\
(1.293)\end{array}$ & $\begin{array}{r}1.166 \\
(1.280)\end{array}$ \\
\hline City of Houston-Buffalo Bayou & $\begin{array}{r}17.99 \\
(11.62)\end{array}$ & $\begin{array}{r}15.06 \\
(11.73)\end{array}$ & $\begin{array}{r}16.27 \\
(11.63)\end{array}$ \\
\hline Clear Creek-Frontal Galveston Bay & $\begin{array}{r}32.87^{\star \star} \\
(16.27)\end{array}$ & $\begin{array}{l}31.51^{*} \\
(16.43)\end{array}$ & $\begin{array}{r}32.33^{\star \star} \\
(16.32)\end{array}$ \\
\hline Cole Creek-Whiteoak Bayou & $\begin{array}{r}23.67 \\
(14.99)\end{array}$ & $\begin{array}{r}23.39 \\
(15.01)\end{array}$ & $\begin{array}{r}22.49 \\
(15.21)\end{array}$ \\
\hline Country Club Bayou-Brays Bayou & $\begin{array}{r}45.64^{\star \star \star} \\
(10.45)\end{array}$ & $\begin{array}{r}40.69^{\star \star \star} \\
(10.64)\end{array}$ & $\begin{array}{r}41.73^{\star \star \star} \\
(10.60)\end{array}$ \\
\hline Garners Bayou & $\begin{array}{r}27.34 \\
(19.18)\end{array}$ & $\begin{array}{r}27.31 \\
(19.13)\end{array}$ & $\begin{array}{r}28.33 \\
(19.26)\end{array}$ \\
\hline Halls Bayou & $\begin{array}{r}49.68^{\star \star} \\
(20.23)\end{array}$ & $\begin{array}{c}47.90^{\star \star} \\
(20.10)\end{array}$ & $\begin{array}{r}53.90^{\star \star} \\
(22.14)\end{array}$ \\
\hline
\end{tabular}

availability with surges in bandwidth demands will be an important point of research as individuals become more reliant on these platforms over time in a time of crisis.

\section{Conclusion}

The results of this study reveal two important findings. First, online social networks undergo statistically significant changes during a crisis, and that these 
Table 4: (continued)

\begin{tabular}{|c|c|c|c|}
\hline & Model 1 & Model 2 & Model 3 \\
\hline Headwaters Greens Bayou & $\begin{array}{c}-17.07^{*} \\
(10.000)\end{array}$ & $\begin{array}{r}-17.85^{\star} \\
(10.00)\end{array}$ & $\begin{array}{r}-17.34^{\star} \\
(9.981)\end{array}$ \\
\hline Hunting Bayou & $\begin{array}{r}81.11^{\star \star \star} \\
(17.25)\end{array}$ & $\begin{array}{l}47.85^{\star} \\
(25.06)\end{array}$ & $\begin{array}{l}49.14^{\star} \\
(25.05)\end{array}$ \\
\hline Jackson Bayou-San Jacinto river & $\begin{array}{r}15.25 \\
(48.49)\end{array}$ & $\begin{array}{r}15.22 \\
(48.26)\end{array}$ & $\begin{array}{r}15.23 \\
(48.34)\end{array}$ \\
\hline Keegans Bayou-Brays Bayou & $\begin{array}{r}48.85^{\star \star \star} \\
(10.87)\end{array}$ & $\begin{array}{r}49.31^{\star \star \star *} \\
(10.80)\end{array}$ & $\begin{array}{r}50.63^{\star \star \star} \\
(10.85)\end{array}$ \\
\hline Little Whiteoak Bayou-Whiteoak Bayou & $\begin{array}{r}24.04^{\star \star} \\
(11.82)\end{array}$ & $\begin{array}{r}23.17^{\star \star} \\
(11.70)\end{array}$ & $\begin{array}{r}22.22^{\star} \\
(11.49)\end{array}$ \\
\hline Lower Greens Bayou & $\begin{array}{l}-1.576 \\
(21.08)\end{array}$ & $\begin{array}{l}-4.720 \\
(20.29)\end{array}$ & $\begin{array}{l}-2.586 \\
(20.42)\end{array}$ \\
\hline Lower Sims Bayou & $\begin{array}{r}19.29 \\
(19.28)\end{array}$ & $\begin{array}{r}16.10 \\
(19.25)\end{array}$ & $\begin{array}{r}17.98 \\
(19.36)\end{array}$ \\
\hline Luce Bayou-Frontal lake Houston & $\begin{array}{r}47.17^{\star \star \star} \\
(7.521)\end{array}$ & $\begin{array}{r}46.03^{\star \star \star} \\
(7.432)\end{array}$ & $\begin{array}{r}46.40^{\star \star \star} \\
(7.410)\end{array}$ \\
\hline Middle Greens Bayou & $\begin{array}{l}-9.762 \\
(40.25)\end{array}$ & $\begin{array}{l}-13.52 \\
(39.82)\end{array}$ & $\begin{array}{l}-12.04 \\
(39.82)\end{array}$ \\
\hline Mustang Bayou & $\begin{array}{r}72.95^{\star \star \star} \\
(9.566)\end{array}$ & $\begin{array}{r}73.47^{\star \star \star} \\
(9.408)\end{array}$ & $\begin{array}{r}73.29 \star \star \star \\
(9.368)\end{array}$ \\
\hline Orange Branch-East Fork San Jacinto river & $\begin{array}{r}-59.29^{\star \star \star} \\
(10.89)\end{array}$ & $\begin{array}{r}-57.93^{\star \star \star} \\
(10.64)\end{array}$ & $\begin{array}{r}-58.06^{\star \star \star} \\
(10.68)\end{array}$ \\
\hline San Jacinto dam-Frontal lake Houston & $\begin{array}{r}29.79 \\
(23.26)\end{array}$ & $\begin{array}{r}32.89 \\
(25.17)\end{array}$ & $\begin{array}{r}30.17 \\
(24.41)\end{array}$ \\
\hline Seaberg Reservoir-Cedar Bayou & $\begin{array}{r}70.93^{\star \star \star} \\
(9.440)\end{array}$ & $\begin{array}{r}70.45^{\star \star \star} \\
(9.367)\end{array}$ & $\begin{array}{r}70.73^{\star \star \star} \\
(9.325)\end{array}$ \\
\hline Spring Branch-Buffalo Bayou & $\begin{array}{r}32.31 * \star * \\
(11.36)\end{array}$ & $\begin{array}{r}36.72^{\star \star \star} \\
(11.11)\end{array}$ & $\begin{array}{r}36.76^{\star \star \star} \\
(11.22)\end{array}$ \\
\hline Upper Greens Bayou & $\begin{array}{c}57.34^{\star} \\
(31.63)\end{array}$ & $\begin{array}{r}17.05 \\
(30.91)\end{array}$ & $\begin{array}{r}17.75 \\
(31.08)\end{array}$ \\
\hline Upper Sims Bayou & $\begin{array}{r}86.15^{\star \star \star} \\
(19.60)\end{array}$ & $\begin{array}{r}84.19^{\star \star \star *} \\
(19.03)\end{array}$ & $\begin{array}{r}85.33^{\star \star \star} \\
(18.90)\end{array}$ \\
\hline Vince Bayou-Buffalo Bayou & $\begin{array}{c}28.30^{\star} \\
(16.68)\end{array}$ & $\begin{array}{r}24.16 \\
(16.30)\end{array}$ & $\begin{array}{r}26.21 \\
(16.41)\end{array}$ \\
\hline White Oak Creek-Frontal lake Houston & $\begin{array}{r}43.04 \\
(40.81)\end{array}$ & $\begin{array}{r}45.66 \\
(38.67)\end{array}$ & $\begin{array}{r}43.92 \\
(40.35)\end{array}$ \\
\hline Constant & $\begin{array}{r}61.09 \\
(45.69)\end{array}$ & $\begin{array}{r}54.42 \\
(46.61)\end{array}$ & $\begin{array}{r}59.09 \\
(45.89)\end{array}$ \\
\hline Observations & 324 & 333 & 331 \\
\hline$R$-squared & 0.200 & 0.186 & 0.192 \\
\hline
\end{tabular}

Robust standard errors in parentheses ${ }^{\star \star \star} p<0.01,{ }^{\star \star} p<0.05,{ }^{\star} p<0.1$. 
changes can linger and have short-term effects on network structural properties. This finding underscores the importance of supporting social media firms and telecommunications and utility companies, who are often among the many unsung heroes during a crisis.

Second, communities active on Nextdoor's platform were more likely to recover at a rate faster than those less active on Nextdoor's platform. In the wake of Hurricane Harvey, the Texas Department of Public Safety estimated that at least 197,000 homes were badly damaged (Wax-Thibodeaux 2018). Three months following Hurricane Harvey, 47,000 Houstonians were living hotel rooms paid for by FEMA (Afiune 2017). In this study, findings from three regression models with robust standard errors and subsequent post estimations of predictive margins reveal the number of days to rebuild went from 127 to 76 days if individuals lived in a community that was active on Nextdoor before Harvey. If they lived in a community active on Nextdoor during Harvey, the rate of rebuilding went from 128 to 69 days. Further, if they lived in a community active on Nextdoor in the month following Hurricane Harvey, the number of days to rebuild went from 128 to 40 . These findings suggest that those who lived in more active Neighborhoods realized the benefits of living in Nextdoor Neighborhoods in the immediate recovery phase following Hurricane Harvey.

This study underscores the importance of investing in and advocating for online and offline hyperlocal community building before, during, and after disasters. Local policymakers and disaster mitigation managers should consider encouraging communities to adopt the use of hyperlocal social media platforms, like Nextdoor, that facilitate social ties and connections at the most local of levels well before a disaster strikes. In addition to leveraging resources to support community building, policymakers at all levels should consider legislation that maintains and strengthens the reliability of telecommunications and energy infrastructure.

Acknowledgments: I would like to express my profound appreciation to Daniel Aldrich for initiating the partnership with Nextdoor in 2014 and inviting me to be a part of such an exciting collaboration. Daniel's willingness to so generously give his time to support this research at every stage, from initial design to completion has been instrumental to the success of this project. A very special thanks to Nextdoor for supporting this research with data that made this analysis possible, and for inviting me to their headquarters to participate in the data acquisition and learn more about Nextdoor's role in communities. A big thanks to Nextdoor team members: Sarah Leary, Sarah Friar, Jennifer Mayfield, Martin Colaco, Carly Villareal, Maryam Mohit, Erica Fagin, Amos Stoltzfus, Nasim Farsinia, Caitlin Lee, and Griffin Okamoto. Finally, I would like to offer my special thanks to Jennie Stephens and Steve Flynn for commenting on early drafts, and Rob DeLeo for his thoughts and feedback on the first conference draft of this manuscript. 


\section{References}

Adeola, F. O., and J. S. Picou. 2012. "Race, Social Capital, and the Health Impacts of Katrina: Evidence from the Louisiana and Mississippi Gulf Coast." Human Ecology Review 19 (1): 10-24, https:// www.jstor.org/stable/24707611.

Afiune, G. 2017. “Harvey was Three Months Ago. These Displaced Families Are Still in Limbo.” In The Texas Tribune. Retrieved from: https://www.texastribune.org/2017/11/21/hurricanharvey-was-three-months-ago-these-displaced-texas-families-ar/.

Airriess, C. A., W. Li, K. J. Leong, A. C. -C. Chen, and V. M. Keith. 2008. "Church-Based Social Capital, Networks and Geographical Scale: Katrina Evacuation, Relocation, and Recovery in a New Orleans Vietnamese American Community.” Geoforum 39 (3): 1333-46.

Aldrich, D. 2011. "The Power of People: Social Capital's Role in Recovery from the 1995 Kobe Earthquake." Journal of the International Society for the Prevention and Mitigation of Natural Hazards 56 (3): 595-611.

Aldrich, D. 2012. Building Resilience: Social Capital in Post-Disaster Recovery. Chicago: The University of Chicago Press.

Aldrich, D., and Y. Sawada. 2015. "The Physical and Social Determinants of Mortality in the 3.11 Tsunami.” Social Science \& Medicine 124: 66-75.

Alliance, D. -P. (2015). Big Data for Climate Change and Disaster Resilience: Realising the Benefits for Developing Countries. Also available at: https://datapopalliance.org/wpcontent/ uploads/2015/11/Big-Data-for-Resilience-2015-Report.pdf.

Bai, H., and G. Yu. 2016. "A Weibo-Based Approach to Disaster Informatics: Incidents Monitor in Post-Disaster Situation via Weibo Text Negative Sentiment Analysis." Journal of the International Society for the Prevention and Mitigation of Natural Hazards 83 (2): 1177-96.

Baird, M. 2010. The Recovery Phase of Emergency Management. Vanderbilt Center for Transportation Research (VECTOR). Retrieved from: https://www.memphis.edu/ifti/pdfs/cait_recovery_phase. pdf.

Beggs, J., V. Haines, and J. Hurlbert. 1996. "The Effects of Personal Network and Local Community Contexts on the Receipt of Formal Aid During Disaster Recovery." International Journal of Mass Emergencies and Disasters 14 (1): 57-78, http://ijmed.org/articles/99/.

Bisri, M. B. F. 2016. "Observing Partnership Innovation Through Inter-Organizational Network Analysis on Emergency Response of the Great East Japan Earthquake and Tsunami 2011." Japan Social Innovation Journal 6 (1): 27-41.

Boase, J., J. Horrigan, B. Wellman, and L. Rainie. 2006. The Strength of Internet Ties. Paper presented at the Pew Internet \& American Life Project.

Bourdieu, P. 1986. "The Forms of Capital." In Handbook for the Theory and Research for the Sociology of Education, edited by J. G. Richardson, 241-58. New York: Greenwood Press.

Brengarth, L. B., and E. Mujkic. 2016. "WEB 2.0: How Social Media Applications Leverage Nonprofit Responses During a Wildfire Crisis.” Computers in Human Behavior 54: 589-96.

Brodkin, J. 2017. An AT\&T Drone is Now Providing Cellular Service to People in Puerto Rico. Retrieved from: https://arstechnica.com/information-technology/2017/11/att-dronebrings-lte-access-to-hurricane-damaged-puerto-rico/.

Burke, M., R. Kraut, and C. Marlow. 2011. "Social Capital on Facebook: Differentiating Uses and Users." Proceedings of the SIGCHI Conference on Human Factors in Computing Systems 571-80, https://doi.org/10.1145/1978942.1979023. 
CBF. 2017. "Ordinary Ctizens in Houston Step Up With Dramatic Fooding Rescues Underway." August 28, 2017. Also available at: https://www.cbsnews.com/news/harvey-tropical-stormhouston-flooding-rescues-ordinary-citizens-step-up/.

Chai, S., and M. Kim. 2010. "What Makes Bloggers Share Knowledge? An Investigation on the Role of Trust." International Journal of Information Management 30 (5): 408-15.

Chamlee-Wright, E., and D. Rothschild. 2007. Disastrous Uncertainty: How Government Disaster Policy Undermines Community Rebound. Arlington, Virginie: George Mason University, Mercatus Center, Mercatus Policy Series. Policy Comment(9), 29.

Chamlee-Wright, E., and V. H. Storr. 2009. "Club Goods and Post-Disaster Community Return." Rationality and Society 21 (4): 429-58.

Chatfield, A. T., H. J. Scholl, and U. Brajawidagda. 2013. "Tsunami Early Warnings via Twitter in Government: Net-Savvy Citizens; Co-Production of Time-Critical Public Information Services." Government Information Quarterly 30 (4): 377-86.

Chen, H. -T., and X. Li. 2017. "The Contribution of Mobile Social Media to Social Capital and Psychological Well-Being: Examining the Role of Communicative Use, Friending and SelfDisclosure." Computers in Human Behavior 75: 958-65.

Chiu, C. -M., M. -H. Hsu, and E. T. G. Wang. 2006. "Understanding Knowledge Sharing in Virtual Communities: An Integration of Social Capital and Social Cognitive Theories." Decision Support Systems 42 (3): 1872-88.

Chu, H., and J. Z. Yang. 2020. "Building disaster resilience using social messaging networks: the WeChat community in Houston, Texas, during Hurricane Harvey.” Disasters, https://doi.org/ 10.1111/disa.12388. https://dx.doi.org/10.1111/disa.12388.

Coleman, J. S. 1988. "Social Capital in the Creation of Human Capital." The American Journal of Sociology 94: S95, https://www.jstor.org/stable/pdf/2780243.

Comfort, L., B. Wisner, S. Cutter, R. Pulwarty, K. Hewitt, A. Oliver-Smith, J. Wiener, M. Fordham, W. Peacock, and F. Krimgold. 1999. "Reframing Disaster Policy: The Global Evolution of Vulnerable Communities." Environmental Hazards 1 (1): 39-44.

Dacy, D. C., and H. Kunreuther. 1969. The Economics of Natural Disasters Implications for Federal Policy. New York: Free Press.

Deng, Q., Y. Liu, H. Zhang, X. Deng, and Y. Ma. 2016. "A New Crowdsourcing Model to Assess Disaster Using Microblog Data in Typhoon Haiyan.” Journal of the International Society for the Prevention and Mitigation of Natural Hazards 84 (2): 1241-56.

Douglas, A. 2017. "Interview With Police Officer Angela Douglas, Houston Police Department Social Media Coordinator on Tuesday." Interviewer: Courtney Page-Tan, October 17.

Dunbar, R. I. M., V. Arnaboldi, M. Conti, and A. Passarella. 2015. "The Structure of Online Social Networks Mirrors Those in the Offline World." Social Networks 43: 39-47.

Dynes, R. 2006. “Social Capital: Dealing with Community Emergencies." Homeland Security Affairs 2 (2): 1-26, https://www.hsaj.org/articles/168.

Edgington, D. 2010. Reconstructing Kobe: The Geography of Crisis and Opportunity. Vancouver: UBC Press.

Elliott, J. R., T. J. Haney, and P. Sams-Abiodun. 2010. "Limits to Social Capital: Comparing Network Assistance in Two New Orleans Neighborhoods Devastated by Hurricane Katrina." The Sociological Quarterly 51 (4): 624-48.

Fagin, E. 2017. "Interview with Erica Fagin in charge of Geospatial Operations at Nextdoor.com on, Thursday, October 5th.” Interviewer: Courtney Page-Tan. 
FEMA. 2017. Historic Disaster Response to Hurricane Harvey in Texas. (HQ-17-133). Retrieved from: https://www.fema.gov/news-release/20200220/historic-disaster-response-hurricaneharvey-texas.

Getchell, M. C., and T. L. Sellnow. 2016. "A Network Analysis of Official Twitter Accounts During the West Virginia Water Crisis." Computers in Human Behavior 54 (C): 597-606.

Gil de Zúñiga, H., N. Jung, and S. Valenzuela. 2012. "Social Media Use for News and Individuals' Social Capital, Civic Engagement and Political Participation." Journal of Computer-Mediated Communication 17 (3): 319-36.

Guan, X., and C. Chen. 2014. "Using Social Media Data to Understand and Assess Disasters." Natural Hazards 74 (2): 837-50.

Haas, J. E., R. W. Kates, and M. J. Bowden. 1977. Reconstruction Following Disaster. Cambridge, Massachusetts: MIT Press.

Hanifan, L. J. 1916. "The Rural School Community Center." The Annals of the American Academy of Political and Social Science 67 (1): 130-8.

Hanneman, R. A., and M. Riddle. 2005. Introduction to Social Network Methods. Riverside, CA: University of California Riverside.

Hau, Y. S., and Y. -G. Kim. 2011. "Why Would Online Gamers Share Their Innovation-Conducive Knowledge in the Online Game User Community? Integrating Individual Motivations and Social Capital Perspectives." Computers in Human Behavior 27 (2): 956-70.

Hawkins, R. L., and K. Maurer. 2010. "Bonding, Bridging and Linking: How Social Capital Operated in New Orleans Following Hurricane Katrina.” British Journal of Social Work 40 (6): 1777-93.

Hayden, M. E. 2017. Hurricane Harvey: Hundreds of Rescues, Thousands of 911 Calls Swamp Houston Area. abc News. August 27, 2017. Retrieved from: https://abcnews.go.com/US/ hurricane-harvey-hundreds-rescues-thousands-911-calls-swamp/story?id=49450092.

Herrera-Yagüe, C., C. M. Schneider, T. Couronné, Z. Smoreda, R. M. Benito, P. J. Zufiria, and M. C. González. 2015. "The Anatomy of Urban Social Networks and its Implications in the Searchability Problem." Scientific Reports 5: 10265.

Horwich, G. 2000. “Economic Lessons of the Kobe Earthquake.” Economic Development and Cultural Change 48 (3): 521-42.

Houston, J. B., J. Hawthorne, M. F. Perreault, E. H. Park, M. Goldstein Hode, M. R. Halliwell, and S. A. Griffith. 2015. "Social Media and Disasters: A Functional Framework for Social Media Use in Disaster Planning, Response, and Research.” Disasters 39 (1): 1-22.

Hurlbert, J., J. Beggs, and V. Haines. 2001. "Social Networks and Social Capital in Extreme Environments." In Social Capital: Theory and Research, edited by N Lin, K Cook, and Ronald B, 209-231. Transaction Publishers.

Hurlbert, J. S., V. A. Haines, and J. J. Beggs. 2000. “Core Networks and Tie Activation: What Kinds of Routine Networks Allocate Resources in Nonroutine Situations?” American Sociological Review 65 (4): 598.

Jamali, M., A. Nejat, S. Ghosh, F. Jin, and G. Cao. 2019. "Social media data and post-disaster recovery." International Journal of Information Management 44: 25-37, https://doi.org/10. 1016/j.ijinfomgt.2018.09.005.

Jonkman, S. N., M. Godfroy, A. Sebastian, and B. Kolen. 2018. "Brief Communication: Loss of Life Due to Hurricane Harvey." Natural Hazards and Earth System Sciences 18 (4): 1073.

Kapucu, N. 2005. "Interorganizational Coordination in Dynamic Context: Networks in Emergency Response Management." Connections 26 (2): 33-48, https://assets.noviams.com/novi-fileuploads/insna/Connections_Archive/2005_Volume_26_Issue_2.pdf. 
Kapucu, N. 2006. "Interagency Communication Networks During Emergencies: Boundary Spanners in Multiagency Coordination." The American Review of Public Administration 36 (2): 207-25.

Kapucu, N., and M. Van Wart. 2006. "The Evolving Role of the Public Sector in Managing Catastrophic Disasters.” Administration \& Society 38 (3): 279-308.

Kapucu, N., T. Arslan, and M. L. Collins. 2010. "Examining Intergovernmental and Interorganizational Response to Catastrophic Disasters.” Administration \& Society 42 (2): 222-47.

Kapucu, N., T. Bryer, and T. Arsian. 2010. "Interorganizational Network Coordination Under Stress Caused by Repeated Threats of Disasters." Journal of Homeland Security and Emergency Management 7 (1): $\mathrm{n} / \mathrm{a}$.

Kim, J., and M. Hastak. 2018. "Social Network Analysis: Characteristics of Online Social Networks After a Disaster." International Journal of Information Management 38 (1): 86-96.

Kittilson, M., and R. Dalton. 2011. "Virtual Civil Society: The New Frontier of Social Capital?" Political Behavior 33 (4): 625-44.

Klinenberg, E. 2002. Heat Wave: A Social Autopsy of Disaster in Chicago. Chicago: University of Chicago Press.

Kryvasheyeu, Y., H. Chen, N. Obradovich, E. Moro, P. Van Hentenryck, J. Fowler, and M. Cebrian. 2016. "Rapid Assessment of Disaster Damage Using Social Media Activity." Science Advances 2 (3): e1500779.

Lachlan, K. A., P. R. Spence, X. Lin, K. Najarian, and M. Del Greco. 2016. "Social Media and Crisis Management: CERC, Search Strategies, and Twitter Content." Computers in Human Behavior 54: 647-52.

Lai, C. H., A. Chib, and R. Ling. 2018. "Digital Disparities and Vulnerability: Mobile Phone Use, Information Behaviour, and Disaster Preparedness in Southeast Asia." Disasters 42: 734-60.

Lassa, J. A. 2015. "Post Disaster Governance, Complexity and Network Theory: Evidence from Aceh, Indonesia after the Indian Ocean Tsunami 2004.” PLoS Currents 7, https://doi.org/10.1371/ $4 \mathrm{f} 7972 \mathrm{ecec} 1 \mathrm{~b} 6$.

Lee, J., and H. Lee. 2010. "The Computer-Mediated Communication Network: Exploring the Linkage Between the Online Community and Social Capital.” New Media \& Society 12: 711-27.

Levin, M. 2017. "How Hurricane Rita Anxiety Led to the Worst Gridlock in Houston History." Houston Chronicle. Retrieved from https://www.chron.com/news/houston-texas/houston/ article/Hurricane-Rita-anxiety-leads-to-hellish-fatal-6521994.php.

Lin, N. 2001. "Building a Network Theory of Social Capital." In Social Capital: Theory and Research, edited by N. Lin, 3-29. New York: Routledge.

Magsino, S. L. 2009. Applications of Social Network Analysis for Building Community Disaster Resilience. Washington, DC: National Academy of Sciences.

Maxwell, K. 2018. “A Coupled Human-Natural Systems Framework of Community Resilience." Journal of Natural Resources Policy Research 8 (1-2): 110-30, https://www.jstor.org/stable/ 10.5325/naturesopolirese.8.1-2.0110.

Metaxa-Kakavouli, D., P. Maas, and D. Aldrich. 2018. "How Social Ties Influence Hurricane Evacuation Behavior.” Proc. ACM Hum.-Comput. Interact. 2 (CSCW): 1-16, https://doi.org/10. $1145 / 3274391$.

Metz, C. 2016. “How Facebook Is Transforming Disaster Response.” In WIRED. Retrieved from: https://www.wired.com/2016/11/facebook-disaster-response/.

Morales, A. J., J. Borondo, J. C. Losada, and R. M. Benito. 2014. "Efficiency of Human Activity on Information Spreading on Twitter.” Social Networks 39 (1): 1-11. 
Murthy, D., and S. Longwell. 2013. "Twitter and Disasters: The Uses of Twitter During the 2010 Pakistan Floods.” Information, Communication \& Society 16 (6): 837.

Nakagawa, Y., and R. Shaw. 2004. "Social Capital: A Missing Link to Disaster Recovery." International Journal of Mass Emergencies and Disasters 22 (1): 5-34, http://ijmed.org/ articles/235/.

Newcomb, Al. 2017. Social Media Becomes a Savior in Hurricane Harvey Relief. NBC News, August 28, 2017. Also available at: https://www.nbcnews.com/tech/social-media/social-mediabecomes-savior-hurricane-harvey-relief-n796701.

Nextdoor. 2020 About Us. Also available at: https://nextdoor.com/about_us/.

Nextdoor. 2020. How to Verify Your Address. Retrieved from: https://help.nextdoor.com/s/ article/How-to-verify-your-address.

NOAA. 2018. What is a Watershed? Retrieved from https://oceanservice.noaa.gov/facts/ watershed.html.

NVOAD. 2019. Hurricane Harvey Facts and Figures. Retrieved from https://www.nvoad.org/ harveyfacts/.

Pang, N., and J. Ng. 2016. "Twittering the Little India Riot: Audience Responses, Information Behavior and the Use of Emotive Cues." Computers in Human Behavior 54 (C): 607-19.

Pinheiro, C. 2011. Social Network Analysis in Telecommunications, 1st ed. Hoboken, New Jersey: John Wiley \& Sons.

Putnam, R. D. 2000. Bowling Alone: The Collapse and Revival of American Community. New York: Simon \& Schuster.

Quinn, K. 2016. "Contextual Social Capital: Linking the Contexts of Social Media Use to Its Outcomes." Information, Communication \& Society 19 (5): 1-19.

Rackin, H. M., and F. Weil. 2015. "Social Capital and the Repopulation of New Orleans after Hurricane Katrina." In Paper Presented at the Annual Meeting of the Population Association of America. San Diego. Retrieved from: http://www.rickweil.com/Writings/ RackinWeil2015PAASocialCapitalandRepopulation.pdf.

Rodriguez, H., T. Wachtendorf, J. Kendra, and J. Trainor. 2006. "A Snapshot of the 2004 Indian Ocean Tsunami: Societal Impacts and Consequences." Disaster Prevention and Management: An International Journal 15 (1): 163-77.

Rosser, J., D. Leibovici, and M. Jackson. 2017. "Rapid Flood Inundation Mapping Using Social Media, Remote Sensing and Topographic Data." Journal of the International Society for the Prevention and Mitigation of Natural Hazards 87 (1): 103-20.

Sanchez, F. 2017. "Interview with Deputy Emergency Management Coordinator, Francisco Sanchez on Monday, October 16, 2017." Interviewer: Courtney Page-Tan.

Sawada, Y., and S. Shimizutani. 2008. "How Do People Cope with Natural Disasters? Evidence from the Great Hanshin-Awaji (Kobe) Earthquake in 1995." Journal of Money, Credit and Banking 40 (2-3): 463-88.

Schweinberger, M., M. Petrescu-Prahova, and D. Q. Vu. 2014. "Disaster Response on September 11, 2001 Through the Lens of Statistical Network Analysis." Social Networks 37 (1): 42-55.

Scott, J. 2012. "History of Social Network Analysis." In What is Social Network Analysis?, edited by I. Ebrary, 7-30. London, New York: Bloomsbury Academic.

Shah, D. V., N. Kwak, and R. L. Holbert. 2001. ““'Connecting” and "Disconnecting” with Civic Life: Patterns of Internet Use and the Production of Social Capital." Political Communication 18 (2): 141-62.

Shi, J., N. Kapucu, Z. Zhu, X. Guo, and B. Haupt. 2017. "Assessing Risk Communication in Social Media for Crisis Prevention: A Social Network Analysis of Microblog." Journal of Homeland Security and Emergency Management 14 (1): 1-16. 
Solnit, R. 2009. A Paradise Built in Hell: The Extraordinary Communities that Arise in Disasters. New York, N.Y.: Viking.

Stefanidis, A., A. Crooks, and J. Radzikowski. 2013. "Harvesting Ambient Geospatial Information from Social Media Feeds." GeoJournal 78 (2): 319-38. Retrieved from https://www.jstor.org. ezproxy.neu.edu/stable/42006322.

Sullivan, K., and P. Holley. 2017. Texans' Do-It-Ourselves Rescue Effort Defines Hurricane Harvey. Washington Post, September 2, 2017. Also available at https://www.washingtonpost.com/ national/texans-do-it-ourselves-rescue-effort-defines-hurricane-harvey/2017/09/02/ f41bb8ee-8f2f-11e7-8df5-c2e5cf46c1e2_story.html?utm_term=.a4baf6ffdd0f.

Sutton, J. N. 2010. "Twittering Tennessee: Distributed Networks and Collaboration Following a Technological Disaster." In Paper presented at the 7th Proceedings of the International Conference on Information Systems for Crisis Response and Management, Seattle, WA, USA. Also available at: http://idl.iscram.org/files/sutton/2010/987_Sutton2010.pdf.

Sutton, J., E. Spiro, C. Butts, S. Fitzhugh, B. Johnson, and M. Greczek. 2013. “Tweeting the Spill: Online Informal Communications, Social Networks, and Conversational Microstructures During the Deepwater Horizon Oilspill." International Journal of Information Systems for Crisis Response and Management 5 (1): 58-76.

Tang, Z., L. Zhang, F. Xu, and H. Vo. 2015. "Examining the Role of Social Media in California's Drought Risk Management in 2014." Natural Hazards 79 (1): 171-93.

Tatsuki, S., and H. Hayashi. 2002. "Seven Critical Element Model of Life Recovery: General Linear Model Analyses of the 2001 Kobe Panel Survey Data." In Paper Presented at the Proceedings of 2nd Workshop for Comparative Study Urban Earthquake Disaster Management. Retrieved from https://www.researchgate.net/profile/Shigeo_Tatsuki/publication/228740239_ Seven_critical_element_model_of_life_recovery_General_linear_model_analyses_of_the_ 2001_Kobe_panel_survey_data/links/554bd37c0cf29f836c98f1f7.pdf.

Taylor, M., G. Wells, G. Howell, and B. Raphael. 2012. "The Role of Social Media as Psychological First Aid as a Support to Community Resilience Building." The Australian Journal of Emergency Management 27 (1): 20, https://ajem.infoservices.com.au/items/AJEM-27-0108.

van Oldenborgh, G. J., K. van der Wiel, A. Sebastian, R. Singh, J. Arrighi, F. Otto, K. Haustein, S. Li, G. Vecchi, and H. Cullen. 2017. "Attribution of Extreme Rainfall from Hurricane Harvey, August 2017." Environmental Research Letters 12 (12): 124009.

Vieweg, S., L. Palen, S. B. Liu, A. L. Hughes, and J. N. Sutton. 2008. Collective Intelligence in Disaster: Examination of the Phenomenon in the Aftermath of the 2007 Virginia Tech Shooting. CO: University of Colorado Boulder.

Wang, Y., and J. Taylor. 2018. "Coupling Sentiment and Human Mobility in Natural Disasters: A Twitter-Based Study of the 2014 South Napa Earthquake." Journal of the International Society for the Prevention and Mitigation of Natural Hazards 92 (2): 907-25.

Wang, B., and J. Zhuang. 2017. "Crisis Information Distribution on Twitter: A Content Analysis of Tweets during Hurricane Sandy." Journal of the International Society for the Prevention and Mitigation of Natural Hazards 89 (1): 161-81, https://doi.org/10.1007/s11069-017-2960-x.

Wang, Z., X. Ye, and M. -H. Tsou. 2016. "Spatial, Temporal, and Content Analysis of Twitter for Wildfire Hazards." Journal of the International Society for the Prevention and Mitigation of Natural Hazards 83 (1): 523-40.

Wax-Thibodeaux, E. 2018. “The 'Harvey Homeless': A Year after Hurricane Harvey Inundated Texas, Some Endure Lingering Effects, Living in Moldy, Water-Ravaged Homes or in Hotels or with Relatives, Because Many Can't Afford Repairs." The Washington Post. Retrieved from 
https://www.washingtonpost.com/graphics/2018/national/hurricane-harvey-aftermathand-recovery/.

Woolcock, M., and D. Narayan. 2000. "Social Capital: Implications for Development Theory, Research, and Policy." The World Bank Research Observer 15: 225-49.

Wu, D., and Y. Cui. 2018. "Disaster Early Warning and Damage Assessment Analysis Using Social Media Data and Geo-Location Information." Decision Support Systems 111: 48-59.

Xiao, Y., Q. Huang, and K. Wu. 2015. “Understanding Social Media Data for Disaster Management." Journal of the International Society for the Prevention and Mitigation of Natural Hazards 79 (3): 1663-79.

Yadav, M., and Z. Rahman. 2016. "The Social Role of Social Media: The Case of Chennai Rains2015." Social Network Analysis and Mining 6 (1): 101.

Zelinsky, D. A., and E. S. Blake. 2018. National Hurricane Center Tropical Cyclone Report. Retrieved from https://www.nhc.noaa.gov/data/tcr/AL092017_Harvey.pdf. 